Рад примљен: 10.02.2019.

Рад прихваћен: 31.03.2019.

\title{
QUESTIONS ON PROTECTION OF CULTURAL HERITAGE ${ }^{* *}$
}

\section{Introduction}

\section{The aim}

The aim of the following lines is to give a summary of the efforts undertaken by international organizations and national legislations, in particular by Greek law, in order to protect the cultural heritage of a country, also called cultural patrimony or cultural property ${ }^{1}$. Greece, since the very beginning, during and after the creation of the modern State, has been very concerned with the protection of cultural objects, and in particular with their international protection, as it often suffers from theft and looting of many elements of its cultural heritage. In order to increase the protection of such objects, this country plays an active role in the international arena, promoting the return and restitution of stolen or illegally exported elements of cultural heritage to their countries of origin.

\footnotetext{
*vrellis@law.uoa.gr

** This paper reproduces the text of a lecture given by the author at the Faculty of Law University of Niš (Center for Private International Law of the Hague Conventions) on the 13th of April 2016.

1 The term cultural heritage seems preferable, though it has been criticized, e.g., by Merryman, 1985: 1911-1916, as being romantic and as expressing a kind of cultural nationalism; nevertheless, being emotionally strong, this term emphasizes more than one factors: a time factor and a national one, which includes, in turn, a cultural element, since cultural identity can be considered as one of the component parts of a nation, affirming and ensuring the identity of the community, to which the item belongs (in a non-strictly legal sense). These factors are always important in order to determine the protected object as well as the degree of the protection. On the concept of the term and on its evolution, see Loulanski, 2006: 207-233.
} 


\section{The risks}

There are two types of risks menacing cultural heritage: those regarding the corporal integrity of cultural objects threatened by war and other analogous activities $^{2}$ or pollution, natural disasters, public and private works, etc; and risks regarding the interest of a country to keep them in its territory on the one hand, and the interest of the owner to keep an object in its possession on the other hand (thefts and illegal exports). The need for protecting cultural objects from a natural or other disaster is generally recognized, at least in theory, because cultural heritage is very important for a country or a nation, as it is for science, in the sense that it collects a great deal of precious information regarding the evolution of the way of life of human communities. Consequently, their protection is very important for mankind as a whole, a factor which led to the use of the term world cultural heritage ${ }^{3}$. The whole mankind has an obvious "interest" that an Egyptian, Syrian, Afghan, Serbian or Greek monument be protected from destruction. Therefore, international Conventions have been concluded in order to enhance cooperation of States for the preservation of cultural heritage, like the UNESCO Convention concerning the Protection of the World Cultural and Natural Heritage (Paris, 16 November 1972).

For jurists, however, the second category of risks carries particular interest, namely with regards to the theft and illegal export of an isolated cultural object or an item removed from a monument. Therefore, we'll insist here on this very issue, which also calls for international cooperation, if not even more so than the first category. Greece is very interested in such cooperation and participated actively in all international negotiations for establishing new instruments within the framework of the UNESCO, the Unidroit, the United Nations or the Council of Europe. It adopted, e.g., the UNESCO Convention on the Means of Prohibiting and Preventing the Illicit Import, Export and Transfer of Ownership of Cultural Property (Paris, 14 November 1970 ), qualified as the most influential document in this area, as well as the Unidroit Convention on stolen or illegally exported cultural objects (Rome, 24 June 1995) ${ }^{4}$. In the EU regime, two other

2 See the UNESCO Convention for the Protection of Cultural Property in the Event of Armed Conflict with Regulations for the Execution of the Convention 1954 (The Hague, 14 May 1954), adopted by Greece and Serbia, and the Protocols; on this Convention Domínguez-Matés, 2008: 851-882; Kamga, 2008: 817-849.

3 The UNESCO established a list of monuments belonging to the world cultural heritage, including among others, e.g., the Palace of Galerius, Stari Ras and Sopoćani, the Studenica Monastery in Serbia; the Acropolis (Athens), the Temple of Apollo Epicurius at Bassae, the Archaeological Sites of Delphi, Olympia, Aigai (modern name Vergina), the Island of Delos in Greece.

4 Regarding this very important Convention, see, e.g. Vrellis, 2003:17-46. For a comparison between this Convention and the Directive 93/7/EEC of the Council, see Siehr, 1998: 671-683. 
instruments are important on this matter: The Council Regulation (EEC) no. 3911/92 of 9 December 1992 on the export of cultural goods (amended several times since) which currently finds its codified version in Council Regulation (EC) no.116/2009 of 18 December 2008 on the export of cultural goods ${ }^{5}$; and the Council Directive 93/7/EEC of 15 March 1993 on the return of cultural objects unlawfully removed from the territory of a Member State (modified later and) recast actually by Directive 2014/60/EU of the European Parliament and of the Council of 15 May 2014 on the return of cultural objects unlawfully removed from the territory of a Member State and amending Regulation (EU) no 1024/12 (corrigendum in OJ L 147, 12.6.2015, p. 24).

The procedure introduced by this Directive was considered as "a first step in establishing cooperation between Member States in this field in the context of the internal market" (recital no. 6 of the Directive 2014/60/EU). The Community had examined the matter as if it were about articles of commerce (see, however, infra, 1.2.1). It thus dealt with them as an exception from the fundamental freedom of circulation of goods into the Common Market. Therefore, it restricted this exception, in only some objects classified, before or after their unlawful removal from the territory of a Member State, among "the national treasures possessing artistic, historic or archaeological value". It would certainly be much better if the Community would deal with such objects not as articles of commerce but rather as elements of the national cultures of member States, all of which enrich cultural diversity; this very diversity seems important for the future of the European Union itself.

\section{The main trends}

Two different trends appear on a global level. One trend stresses the interest of a usually economically poor but culturally very rich State to keep a cultural object in its territory. Such an interest is extremely important for the history of the country and the identity of the people. This feeling - affirming the continuity and the identity of a nation - has been qualified by the partisans of the second trend as romantic and nationalistic (supra, note 1). Beside this unjust blame, the second trend refers to the trade freedom as a general principle, covering both usual articles of commerce and objects of art, including cultural objects wrongly assimilated to objects of art. Consequently, according to that second trend, a cultural object must be freely sold in its initial country (country of origin), then be transferred to another country, sold there, etc. Even a cultural object stolen in its country of origin and transferred to another country may

5 The Regulation establishes a Community system to protect Member States'cultural heritage from illegal exportation out of the Community borders to non-Member States. 
be (according to the same trend) legally acquired by a bona fide purchaser, sold further to another person and entered into the market. This second trend, socalled internationalistic, is supported in particular by persons involved in art trade, art dealers and countries economically rich but culturally rather poor. These countries want to collect cultural objects from all over the world, make profit by organizing auctions in their own territory (e.g. Sotheby's in London or Christies), enrich their museums, and they allege that they are in a better position to safeguard the corporal integrity of cultural objects, which are threatened at their home countries with war or other analogous activities or pollution or natural disasters or pillage etc ${ }^{6}$. Thus, they save, as they often cynically pretend, said objects from destruction risks and offer to their citizens and the visitors, opportunities of enjoyment and cultural development. To be sincere, one must stress the fact that the global annual turnover in art market is enormous, analogous to a large extent to that in weapons, and this is a factor stimulating the increase of the illegal trafficking of cultural objects; a traffic which many wish to transform or disguise into legal trade by invoking some well-known rules of private and private international law, such as the protection of a bona fide possessor or the lex rei sitae.

Our subject will be limited to the exploration of two main questions: (1) What are the protected items? (2) How are they protected, in particular on the international level?

\section{Chapter 1: The protected items}

Concerning the definition of cultural objects, two particular problems arise: (a) How are they defined? (b) Do all these objects merit protection, and if so, do all of them merit protection to the same extent?

\subsection{How to define a cultural object}

Two specific points require more attention:

\subsubsection{Who must have the competence for qualifying an item as a cultural object?}

A first possible answer is that each State may define which items are considered as cultural objects according to its own law. The other States have to recognize

6 Such an allegation is not true. E.g., the fragments of the Parthenon temple (Athens), illegally removed and partly destroyed by Lord Elgin (the so-called Elgin Marbles), have been damaged at least twice there, although many had pretended that it was safer for the antiquities to be kept in the British Museum instead of being rendered to Greece, where they were exposed to pollution: (1) when the British Museum, in which they are, awkwardly attempted to clean them; and (2) quite recently, when the room in which the fragments are exhibited has been submerged after a heavy rain. 
that definition. This solution has been adopted by the UNESCO Convention (Paris, 1970). Article 1 states, "For the purpose of this Convention, cultural objects are those which, on religious or secular grounds, are designated by each State as being of importance for archaeology, prehistory, history, literature, art or science and belong to one of the following categories [...]"; an analytical list of items follows thereafter. Such a solution affirms the principle of mutual recognition of national legislations on the point at hand. In other words, a State recognizes and considers as a cultural object an item which is qualified and protected as such by the legal system of another State. It is obvious that the partisans of a very broad protection of cultural objects are in favor of such a wording.

A similar reference to the domestic legislation is to be found in the Directive 2014/60/EU as well as its initial version (Directive 93/7/EEC). In this instrument, however, the definition is far more restricted, since it is limited to a restricted number of very important cultural objects, those classified as national treasures of the relevant Member State, within the meaning of Article 36 of the Treaty, and belonging to one of the categories listed in an Annex or forming integral parts of public collections, etc ${ }^{7}$. The scope of the new version (Directive 2014/60/ EU) is more extensive, covering (i) any cultural object classified or defined by a Member State as a national treasure, (ii) whether or not such objects form part of public or other collections or are single items, and (iii) whether or not they originate from regular or clandestine excavations.

A different solution has been adopted by the Unidroit Convention (Rome, 1995). Article 2 (the outcome of hard negotiations in Rome) repeats the UNESCO definition, and is accompanied with the same analytical enumeration of items in an Annex, but without any reference to the State's legislation. It is an autonomous definition for the purpose of the Convention, not depending on the national legislation of the Contracting States. Consequently, an item qualified as a cultural object by the State of its origin may not be qualified or protected as such by the Unidroit Convention.

\subsubsection{What are in principle the items which may be qualified as cultural objects?}

There are many answers to this question.

In various national, European and international texts, one may come across definitions which, on the one hand, combine and accumulate some abstract and general elements (e.g. an item which, on religious or secular grounds, is of importance for archaeology, literature, art, science etc.) with some other rather

7 That Annex contained various items, among them archaeological objects, photographs, films, books etc. 
concrete and detailed elements, on the other hand (e.g. an item belonging to inventories of institutions) [see Council Regulation (EC) no 116/2009].

Domestic legislations define cultural objects using either some vague and more or less broad wording (this is the case e.g. in Canada, Japan, Portugal, Finland, Greece, and other countries) ${ }^{8}$ or a system of classification, registration or inventory, in order to protect exclusively the registered or inventoried items ${ }^{9}$. The second system may appear simple and satisfactory (and useful for the international art trade), but in reality it is not at all satisfactory because (i) a great number of poor countries with a rich and ancient cultural heritage, are not able, to finance such inventories; and (ii) the most vulnerable cultural objects, those unlawfully excavated, remain without any protection, just because they are unknown and consequently they cannot be inventoried.

Sometimes national legislations adopt extremely broad definitions of cultural objects. This is, for example, the case of Greek Act no 3028/2002 on the protection of Antiquities and Cultural Heritage in general ${ }^{10}$. Article 2 letter (a) of the Act, without using any list of items, simply states that "Cultural objects shall mean testimonies of the existence and the individual and collective creativity of humankind (human beings)"11. This means that actually any product of human activity, as an element of safeguarding the historic memory of human beings constitutes a cultural object and, consequently, it forms part (under some conditions) of the protected cultural heritage of the Country. Obviously, such a general definition is not appropriate for identifying positively the items deserving a specific protection. On the contrary, in a sense, it would be dangerous: If every testimony of a human activity were effectively protected, future creations would be in some way prohibited or scarcely realizable, for lack of space in a narrow piece of land of a small country where culture has been developing for millennia. Thus, it is necessary to find an appropriate criterion, in order to specify the items deserving an increased protection.

8 See in Vrellis, 1996: 221-222.

9 Cf. the UNESCO Recommendation for the Protection of Movable Cultural Property of 28 November 1978, art. 12 letter (a).

10 See Vrellis, 2004: 1779-1788.

11 Besides the tangible cultural heritage Greek law and international Conventions actually protect intangible cultural objects as well. See art. 5 of the Act, which preceded the UNESCO Convention of 17 October 2003 for the Safeguarding of the Intangible Cultural Heritage (ratified among others by Greece and Serbia). However, it seems doubtful whether or not we are already mature enough to establish a satisfactory system of protection of the intangible cultural heritage, if something like that really exists. 


\subsection{Are all these objects worth being protected to the same extent?}

In order to protect a cultural object, various international instruments, like the UNESCO and the Unidroit Conventions, require that it must be of importance for archaeology, history, literature, art or science, etc.

This condition presents a twofold aspect: (a) the importance as a concept, and (b) the degree of the importance.

\subsubsection{The importance as a concept}

The importance (as a concept) of a cultural object shall not be linked with its financial value. A piece of textile of no earthly use may have an extremely high moral and historic value for a State or a nation, because it is the bloodstained flag of that nation fighting for freedom. Evaluating the importance of an item on the base of its price in the market is an idea completely incompatible with the ratio of protecting cultural objects. However, Council Regulation (EC) no 116/2009 and the initial Directive 93/7/ EEC required for the protection of some categories of cultural objects (like drawings, photographs, books, pictures etc) that they have a minimum price in the market. Fortunately, under the new version (Directive 2014/60, Recital 9), cultural objects classified or defined as national treasures no longer have to belong to categories or comply with thresholds related either to their age or financial value in order to qualify for return under the Directive.

In the UNESCO's and the Unidroit definitions of cultural objects, the importance of the item has to do with archaeology, history, literature, art, etc. This link has a temporal and a cultural aspect. On the one side, for many cultural objects like those being important for paleontology or history, the critical factor is that of their age; on the other side, for other cultural objects, like those being important for art, the critical factor is obviously the cultural one ${ }^{12}$.

\subsubsection{The degree of importance}

Greek Law proceeds to specific and precise distinctions, making dependent the degree of protection reserved to a cultural object/monument on the degree of its importance: The importance of a monument mainly refers to its age ${ }^{13}$. The general

12 In a similar way, Greek Law tries to identify the protected cultural objects through another, additional concept, i.e. that of the monument. The monument is a narrower concept than that of cultural object. The terminology used by Greek Act no 3028/2002 is rather confusing, but one might affirm that the Monuments are the tangible cultural objects which are protected or worth being protected by the law, either because of their age or their intrinsic cultural importance.

13 Council Regulation (EC) no. 116/2009 too takes into consideration a time factor, covering, e.g., archaeological objects or books more than 100 years old, printed maps more than 200 
rule is: More ancient items are more protected; more recent items are less protected. Regarding the recent objects, a cultural factor appears: modern monuments are worth being protected on the ground of their cultural (historic, artistic or scientific) importance. More particularly, the main distinction adopted by the Greek Act, reiterating the previous rules, is the distinction between monuments dated from the very remote past until the year 1830 inclusive (ancient monuments) and those dated after this year (modern monuments) ${ }^{14}$. Without entering into quite complicate details, it suffices to stress an additional distinction inside the frame of ancient monuments: the Act distinguishes between ancient monuments dated until 1453 A.D. ${ }^{15}$, and those dated after 1453 until 1830.

A.1.a. All the ancient monuments (movable and immovable) dated until 1453 (i.e. coming from the prehistoric period, from antiquity or from the Byzantine period) enjoy the maximum protection: They are considered monuments ex lege; they are extra commercium, barred from acquisition by way of usucapio, and not subject to seizure. The immovables in principle are the ownership of the State, which is also their possessor ${ }^{16}$. The movables in principle belong to the State as regards their ownership and possession, albeit with exceptions: (a) Rights of ownership over religious movables already belonging to the Church or to other ecclesiastical or religious bodies and institutions, remain; (b) the rights of ownership of individuals over such movables, legally imported into Greece, are recognized under conditions, if they are not the result of an excavation, and may be transferred either inter vivos or mortis causa. A permit of a singular possession of movables belonging to the State may be granted to individuals by decision of the Minister of Culture. The transfer of that possession may be permitted, usually after approval of the Minister of Culture, in preference towards other public bodies and institutions or other legal persons, in order to be displayed in a collection of a museum. Any transfer taking place in violation of the mentioned rules is null and void. They cannot be legally acquired even by a bona fide purchaser, and even though they are bought in an auction house or in an open market.

b. The same system seems to apply grosso modo to the ancient monuments (movable or immovable) dated after 1453 (until 1830, of course), which are found during an excavation or any other archaeological research, or are detached from immovables.

years old, archives more than 50 years old etc.

14 After the revolution against the Ottoman Empire, the year 1830 marked the birth of the modern Greek State.

15 The year 1453 is the end of the Byzantine Empire.

16 There is one exception to the ownership of the State: ownership over religious immovables already belonging to the Church, or to other ecclesiastical or religious bodies and institutions, remains. 
2. Regarding ancient monuments dated after 1453 (until 1830) but not falling within the exceptional categories just mentioned, namely items discovered during an excavation or detached from an immovable, such items are less protected. The Act distinguishes between immovables and movables. (i) Immovables are monuments ex lege; the State remains their owner, but the possibility of other persons beyond the State to acquire the ownership over them is nevertheless recognized. (ii) On the contrary, in order to be protected, movable monuments dated after the year 1453 but before the year 1830 inclusive, not discovered during an excavation (etc.) must be qualified as monuments by virtue of a decision of the Minister of Culture (as modern movable monuments), due to their "social, technical, folkloric, ethnological, artistic, architectural, industrial or in general historic or scientific importance". The crucial element for their protection is not their age but their cultural importance. They may exceptionally belong to persons other than the State, even to individuals; in that case, they may be seized under a specific procedure and the right of ownership over them may be transferred under conditions. When they are the ownership of the State, their possession by other persons may be permitted by a decision of the Minister of Culture.

B.1. Modern monuments (i.e. those dated after 1830) are protected, not because of their age but because of their "architectural, town planning, social, ethnological, folkloric, technical, industrial, or in general historic, artistic or scientific" importance. It is precisely this significance that leads the Minister of Culture to qualify such objects as "monuments" and grant them protection, since they are not protected ex lege. The time elapsed since their creation is relatively short and, consequently, does not suffice for protecting them. At this moment, the criterion of cultural importance intervenes and balances the youth of age. Individuals are allowed to acquire ownership over all modern monuments and exercise it under conditions. It is worth noting that (unlike other movable items) a movable monument, stolen or lost, cannot be legally acquired a non domino from a third person, even though the latter is bona fide and even though he bought it in an auction or in an open market.

2. It is worth stressing a distinction made by the Act between less modern and more recent monuments. The latter must be particularly important in order to be qualified as monuments: (a) The modern cultural objects created in a period before the last 100 years are qualified as monuments due to their cultural importance (in the above sense); but (b) the modern cultural objects dated within the period of the last 100 years (i.e. from today back to 1919; the more recent modern objects) may be qualified as monuments due to their particular cultural importance (in the mentioned sense). The discretion of the Ministry, though under the judicial control of the Conseil d'Etat (the Administrative Supreme 
Court in Greece), seems extensive, all the more so as this Court had in the past interpreted very widely the historic importance of a building (e.g. an open-air cinema). It seems advisable that a corrective criterion should be introduced in order to restrict the over-extensive ministerial power of qualification, and not to allow the qualification of an object of art as a monument, as long as the intellectual property rights over this object remain ${ }^{17}$.

The system established by Greek Law is a moderate position between two extremes: on the one hand, the opinion considering that every cultural object is important by itself and must be protected at the highest level, and, on the other hand, the opinion supporting that only a more or less restricted number of items of great or significant importance (the cultural treasures) are worth being protected.

\section{Chapter 2: Cultural objects' protection on international level}

It is noted supra that theft and illegal export of a cultural object are particularly interesting for jurists, and especially on the international level. All States have an interest to keep their own cultural heritage under their control and in their territory, or to recover it. A first crucial issue in this respect is the nationality/ origin of a cultural object. Does a concrete item belong to State (country, community, tribe) X or to State (country, community, tribe) Z?

\subsection{The nationality of a cultural object}

\subsubsection{The importance of the question}

In case where the same object is claimed by two or more different States, and has to be restituted to its national State, i.e. to the State of its origin, it is absolutely necessary to know exactly to which of them it must be returned. The solution is sometimes very difficult. Let us suppose, for instance, that an object belongs to a culture (e.g. of pre-Columbian era), which has been developed in the territory of more than one actual States (e.g. Mexico, Peru and other countries in Latin or South America). This object has been illegally excavated somewhere in the general area of that culture, but the place of the excavation remains unknown. It has been consequently found in a third country (U.S.A.), where it is claimed by more States (Mexico and Peru). There is no easy answer to the question which is the State of origin of that object, to which it has to be returned.

Besides, it is interesting to know whether a State, which affords an increased protection to its national cultural objects, is ready to provide for an analogous

17 For more details see Vrellis, 2006: 429-442. 
protection of foreign cultural objects, for example in returning them to their country of origin in case of an illicit exportation from that country. Countries adopt various solutions. For example, Canada, Australia and the USA have established a rather efficient protection regarding foreign cultural objects, proceeding to a control of the legality of their export from their Country of origin, at the moment of their import into their territories. Greek Law aims to protect in the first place the cultural heritage of the Country (Article $1 \S 1$ ). Thus, the import of cultural objects into Greece is in principle free, under the condition that the UNESCO Convention of 1970 and other rules of International law are respected ${ }^{18}$ (in general, this means that the imported items should be legally exported from their Countries). On the contrary, the export of monuments from Greek territory is in principle forbidden and may lead to imprisonment and confiscation of the items ${ }^{19}$. At the European level, Council Regulation (EC) no. 116/2009, estimating "necessary to take measures in particular to ensure that exports of cultural goods are subject to uniform controls at the Community's external borders" (Preamble no. 3), stipulates that, in principle, "the export of cultural goods [in the meaning of the Regulation] outside the customs territory of the Community shall be subject to the presentation of an export licence" (Article $2 \S 1$ ), which "shall be valid throughout the Community (Article $2 \S 3$ ) ${ }^{20}$. Regarding the introduction and import into the customs territory of the Union of cultural goods, inter-institutional negotiations on a "proposal for a regulation of the European Parliament and of the Council on the import of cultural goods" have recently led to a compromise ${ }^{21}$.

18 In case of violation of international rules, criminal sanctions are provided (art. 64-65 of the Act).

19 Exceptionally, under specific circumstances and conditions, and in general, after permission by the Ministry of Culture, the export of monuments is permitted, e.g. for the purpose of their display in museums or for loaning or exchange, research, educational or conservation purposes (art. $34 \S 11$ of the Act).

20 Commission implementing Regulation (EU) No 1081/2012 of 9 November 2012 for the purposes of Council Regulation (EC) no. 116/2009 on the export of cultural goods (see Corrigendum in OJ L 93, 28.3,2014, p. 86), which codified Commission Regulation (EEC) no. 752/93 of 30 March 1993, laying down provisions for the implementation of Council Regulation (EEC) no. 3911/92, establishes (arts. 1-2) three types of licences for the export of cultural goods: (a) a standard licence, "normally [...] used for each export subject to Regulation (EC) no. 116/2009"; (b) a specific open licence, covering "the repeated temporary export of a specific cultural good by a particular person or organization"; and (c) a general open licence, covering "any temporary export of any of those cultural goods that form part of the permanent collection of a museum or other institution".

21 See the text of the provisional agreement upon that proposal, available at http://www. europarl.europa.eu/RegData/commissions/imco/inag/2019/01-16/CJ33_AG(2019)632807_ EN.pdf 


\subsubsection{Criteria of nationality}

Various criteria have been advanced in order to designate the nationality of a cultural object: (a) A personal criterion, not quite satisfactory: as State of origin is considered the State whose nationality has the creator of the object. ${ }^{22}$ Personal criterion is sometimes combined with a territorial one, like in Swedish law on cultural heritage (1989), Ch.5 s.2: "The term Swedish items of historic interest refers to items which were actually or presumably made in Sweden or in some other country by a Swede. The term foreign items of historic interest refers to items made in another country by a non-Swede".

(b) A territorial criterion with various nuances: as State of origin is considered the State in the territory of which the cultural object has been found during an excavation (very satisfactory criterion), or has been created, or it has been located there for many years and has been somehow "naturalized" there.

(c) A functional criterion (often very satisfactory), which means the link of the object to a monument (a temple) in which the object was used or which it was intended for. According to this criterion, the sculptures and reliefs of the Parthenon in the Acropolis in Athens, illegally removed by Lord Elgin at the beginning of $19^{\text {th }}$ century and retained by the British Museum, must be returned to the monument (the Parthenon, i.e. to Greece).

(d) A contractual criterion: The State of origin is that which legally obtained the object from its owner.

(e) A cultural criterion, i.e. the link to the history or the culture of a State, has been proposed by the Institute of International Law in 1991 at Basel. Article 1 $\$ 1$ (letter b) of the Resolution on the International Sale of Works of Art from the Angle of the Protection of the Cultural Heritage states: "For the purpose of this Resolution: [...] b) 'country of origin' of a work of art means the country with which the property concerned is most closely linked from the cultural point of view". The cultural criterion may be very interesting but sometimes quite difficult to apply.

(f) Combined criteria: The UNESCO Convention of 1970 on the means of prohibiting and preventing the illicit import, export and transfer of ownership of cultural property attempted to combine various criteria in Article 4, without any priority among them: "The States Parties to this Convention recognize that for the purpose of the Convention property which belongs to the following categories forms part of the cultural heritage of each State: (a) Cultural property created by the individual or collective genius of nationals of the State concerned,

22 See New York Court of Appeals 2nd cir. (1982), on the case of Matisse, Portrait sur fond jaune. 
and cultural property of importance to the State concerned created within the territory of that State by foreign nationals or stateless persons resident within such territory; (b) cultural property found within the national territory; (c) cultural property acquired by archaeological, ethnological or natural science missions, with the consent of the competent authorities of the country of origin of such property; (d) cultural property which has been the subject of a freely agreed exchange; (e) cultural property received as a gift or purchased legally with the consent of the competent authorities of the country of origin of such property". The weakness of this approach is the risk that the same object could be considered as having more than one State of origin.

\subsubsection{Criteria established by Greek Law ${ }^{23}$}

(i) A kind of combination of territorial and cultural criteria is established by Greek Law. too. The main criterion is territorial: The actual situs of the object. The principle is rather simple: Every cultural object, which is located within the boundaries of the Greek State, including the territorial waters, as well as within other maritime zones over which Greece has relevant jurisdiction according to international law (i.e. the underwater cultural heritage ${ }^{24}$ ), is considered to be part of the Greek cultural heritage (Article $1 \S 2$ first sentence of the Act no 3028/2002). The concept of underwater cultural heritage includes sites, cities [like the ancient cities (lost under the water) of Keghréai (partly under the sea) and Helike (in Greece)] ${ }^{25}$, structures [like the Beacon at Alexandria (Egypt)], buil-

23 See Sp. Vrellis, 2006: 442-446.

24 The underwater cultural objects are a very important category of cultural objects, both for archeologists and jurists, scientifically and financially; they run the danger of being looted by treasure hunters; Williams, S. (1997), Patrimoine sous-marin: La course aux trésors, Sources UNESCO no 87 (février 1997), p. 7-8 [Electronic version]. Retrieved 20 February 2016, from https://unesdoc.unesco.org/ark:/48223/pf0000105111_fre

25 Regarding Helike, an important trading port in the Gulf of Corinth, destroyed and submerged -probably not by the sea but by an inland lagoon, which later silted over- on a winter night in $373 \mathrm{BC}$, after a catastrophic earthquake and tsunami, see https://en.wikipedia. org/wiki/Helike, and Katsonopoulou, Soter, (2005) in http://www.helike.org/paper.shtml. 
dings, human remains, vessels ${ }^{26}$, aircraft, other vehicles or any part thereof, their cargo or other contents ${ }^{27}$, which have been partially or totally under water ${ }^{28}$.

The actual situs, as the main criterion according to Greek Law, seems on the one hand too extensive and, on the other hand, quite restrictive. There are cultural objects, located in Greece, which do not belong to Greek culture. There are also cultural objects belonging to Greek culture, created by Greek people, but not located in actual Greek territory, and therefore not belonging to the Greek cultural heritage.

(ii) The authors of the Act in Greece tried to broaden the purely territorial criterion. Article $1 \S 3$ states that "within the framework of the rules of international law, the Greek State also takes care of the protection of cultural objects that hail from Greek territory, regardless of the time of their removal. The Greek State also takes care within the framework of international law, of the protection of cultural objects that are historically connected with Greece, wherever they may be located". Whatever the real meaning of this wording might be actually it seems dubious enough), the law recognizes that the State has a reasonable interest, within the framework of international law, in the protection of such cultural objects, provided that they have a link with the State. This link has a double aspect: a territorial one (the provenance of the object from Greek territory) or a cultural one (the historical connection of the object with Greece).

26 Shiprecks and their cargo are very well protected, as they are covered by the mud on the seabed (a phenomenon called The Pompei effect). Therefore, they offer us precious information about the trade, the ship-construction, and the life of the crew in the Antiquity. One of the oldest known underwater shipwrecks is the Dokos shipwreck (Early Helladic II period, probably around $2200 \mathrm{BC}$ ), discovered near the small island of Dokos, off the coast of the Peloponnese and excavated later; for more details see http://web.archive.org/web/20080121231045/ http://www.ienae.gr/e107EN/page.php?6. Another very important cultural object is The wreck at Point Iria (around 1200 BC), discovered in 1962, but systematically surveyed over four excavation seasons from 1991 to 1994; for more details see http://web.archive.org/ web/20080121231050/http://www.ienae.gr/e107EN/page.php?7

27 A very important underwater cultural object is the Mechanism of Antikythera $\left(2^{\text {nd }}\right.$ or $1^{\text {st }}$ century B.C.), found by chance in 1900 in a shipwreck at the bottom of the sea of Antikythera (a small island between the Peloponnese and Crete, Greece). Through high-technology instruments, the scientists concluded that it was a kind of an analog computer, designed to predict astronomical positions and eclipses for calendrical and astrological purposes, as well as the Olympiads (i.e. the cycles of the ancient Olympic Games). For more details see, https:// en.wikipedia.org/wiki/Antikythera_mechanism, http://www.antikythera-mechanism.gr/ project/overview.

28 Cf. the UNESCO Convention on the Protection of the Underwater Cultural Heritage (Paris, 2 November 2001), art. $1 \S 1$ (not ratified by Greece); regarding this Convention see Dromgoole, 2006: passim; Vrellis, 2005: 823-840; Zhao, 2008: 601-641; Trevisanut, 2008: 643-686. 
The first sentence of Article $1 \S 3$ concerns items which are no longer within Greek territory, but they hail from it. This provenance has an exclusive territorial meaning: The relevant cultural objects were in the past found or located inside the Greek State, but they have been taken away from it and they are no longer in Greece. They do not need to belong to Greek civilization or to be items culturally linked with the Greek world. The time of their removal is from the law point of view irrelevant. These items must be protected by Greek law. But, due to the fact that they actually are not in Greece, they cannot be protected effectively. Therefore, the Greek State must take care for their protection, in the framework of the rules of international law, e.g., in the framework of the UNIDROIT Convention (1995).

The second sentence of Article $1 \S 3$ introduces a factor justifying the interest of the Greek State in the protection of a cultural object which is not in Greece. This factor is the cultural object's historical connection with Greece. It is worth being observed that the situs of the item is here completely irrelevant. Any territorial connection with Greek territory vanishes. The concrete object may never have been in Greece. It nonetheless attracts the care of the Greek State because of a factor of cultural nature, i.e. its historical link with Greece.

The Law system, despite the ambiguity of the terminology in various points, reflects nevertheless a spirit of realism, in distinguishing (on the one hand) the effective protection of the cultural objects which are actually in Greece, a protection which can be secured by the State, and (on the other hand) the care for objects which are beyond its sovereignty. The rule is quite flexible because it links the extent of care, which may be manifested by the Greek State, with the development of international law.

\subsection{Recovering stolen or illegally exported cultural objects}

What is particularly interesting for jurists is the respect of the legitimate interest of the State of origin in keeping its cultural objects in its territory and not permitting their export without an authorization of the competent national authority ${ }^{29}$. Despite all kind of national interdictions or control of export, the illegal removal or traffic of cultural objects is an undeniable fact of enormous dimensions. This phenomenon raises the question of the acquisition of the ownership in cultural objects by a bona fide purchaser and the question of return of the removed object to its State of origin.

29 See, more generally, Siehr, 1993: 9-292. 


\subsubsection{Refusing the recovery}

Two well-known cases may enlighten the situation:

(1) The case Winkworth v Christie [(1980) 1 All ER 1121] regards stolen goods: Works of art were stolen from an Englishman's house in England. They were taken to Italy and sold there to an Italian man who, then, sent them back to England to be auctioned by Christie. Applicable in England and in Italy as well was Italian law, according to a widely adopted conflict-of-laws rule, providing as applicable to the transfer of ownership the law of the Country in which the object is situated (the lex rei sitae) at the moment of the transfer of its ownership. Under Italian law, the Italian buyer obtained bona fide the ownership of the items, albeit they were stolen. The House of Lords recognized the ownership thus acquired, and rejected the claim of the ancient owner although, under Anglo-Saxon Laws, stolen items can never be legally acquired, even by a bona fide purchaser. But, English Law was not applicable to the case because it was not the lex rei sitae at the critical moment. In substance, between the ancient owner, deprived of his rights and the bona fide purchaser, the Court preferred the latter. In my view this was a bad judgment although it applied strictly the traditional way of thinking of such issues in private international law. The evil had two roots: (a) the conflict-of-laws rule submitting the ownership in cultural objects to the lex rei sitae ${ }^{30}$; (b) the domestic (Italian) law, according to which a bona fide purchaser acquires the ownership in a cultural object even though the latter was stolen.

(2) The case Attorney General of New Zealand v Ortiz [(1982) 3 All ER 432 (CA); (1983) 2 All ER 93 (HL)] regards the illegal export. Five wooden panels, forming the great door of a Maori chief, had been lost for centuries in a swamp in the North Island. In 1972, a tribesman came upon the door and carried it home. In early 1973, this man sold the panels to an English dealer in primitive art works for \$ US 6,000. The dealer, who legally became the owner in New Zealand, took the panels illegally to New York. In case of illegal export from the Country, even by their owner, the items were considered as automatically confiscated by the Crown. Then, the dealer sold the door to George Ortiz, a collector of African and Oceanic works of art living in Switzerland. Ortiz bought the door for \$ US 65,000 and sent it to his collection in Geneva. As his daughter had been kidnapped and he needed ransom money to obtain her release, he had to put the panels up for sale in 1977. The panels were sent to Sotheby's in London for auction. The New Zealand Government became aware of this, and brought proceedings in the British Courts; a writ was issued claiming a declaration that this carving

30 Sometimes, casually, the traditional application of the lex rei sitae may work out at satisfactory results, as it was the case regarding cultural objects of Ecuador; see Clerici, 1989: 804-805. 
belonged to the New Zealand Government and an injunction to prevent the sale or disposal of the door. The Court of Appeals and the House of Lords decided that the panels need not be returned to New Zealand because English Courts could not take into account foreign laws of public or penal character like the New Zealand laws on export and confiscation of cultural objects, since such laws have no effects out of the territory of the State which had established them. This was a bad decision, too, because the preponderant and legitimate interest of the State of origin, which demands that the item continues to be in any case located in its territory, has been neglected ${ }^{31}$.

\subsubsection{Efforts at facilitating the recovery}

Many efforts have been undertaken at the international level in order to ameliorate this situation, and facilitate the recovery of the objects. At the same time, extremely important Codes of Ethics (adopted by Museums, Associations, etc.) aim to prevent Museums from acquiring cultural objects of shady or suspicious provenance ${ }^{32}$.

(a) One possibility to recover stolen or illegally exported cultural objects is to carry on negotiations with the possessor of the objects. Negotiations may be efficient and prompt but they are not always free from inconvenience. One example is the Aïdonia Treasure ${ }^{33}$.

(b) (i) The opinion adopted in Ortiz case that a foreign public law, like an Act prohibiting the export of the items and providing the confiscation of the illegally exported items, cannot be applied in another State became less strong during the last decades. Actually, there are many who do not see anymore an impedi-

31 It must be noted that Ortiz's surviving wife agreed to return the five panels to New Zealand. They are now housed at the local Puke Ariki Museum.

32 See e.g. ICOM code of ethics for museums Principles 2.2 and 2.3. The Principles of such Codes are not legal rules in the strict sense of the term. Nevertheless, they are very useful, and they form the corn of what may be called lex cultus; Vrellis, 2014: 477-486.

33 The Aidonia Treasure is a collection of Mycenaean gold and jewellery (1 $5^{\text {th }}$ century BC), which has been robbed in the late 1970s from a cemetery at Aidonia, a southern Greek village outside Nemea, and exported to Switzerland. In April 1993, part of the treasure appeared for sale in New York by the Ward Gallery in Manhattan. The price asked was $\$ 1.5$ million. The study of the catalog and of an Expert Committee revealed that "these objects came undoubtedly from the looting of the Mycenaean tombs in Aidonia". As Greece claimed the collection, a settlement was reached between the Gallery and Greece: in exchange for Greece dropping its suit, the Gallery donated the Mycenaean material to the Society for the Preservation of the Greek Heritage, a charitable organization based in Washington, D.C. The Society would exhibit the collection in the United States and Greece and might eventually return it to Greece on a permanent basis. See further Elia, 1995: 119-128. 
ment to the taking into account such foreign rules in the State in which a foreign cultural object is imported.

(ii) Moreover, the respect of these foreign rules is sometimes considered as imposed by the international ordre public, as decided on 22 June 1972 in Germany $[B G H Z 59 \text { 82, regarding Nigerian cultural objects }]^{34}$. (iii) Further, such rules may be considered as overriding mandatory rules (règles d'application immediate), which must be respected, so it is argued, not only in the State which established them but also in foreign States. One can find an example of such a position in the Greek legislation (Act no. 3658 of 2008, Article $13 \S 3$ ), which considers the Act 3018/2002, in its entirety, as overriding mandatory, and combines this with the exclusive international competence of Greek Courts (Article $13 \S 1^{35}$ ). However, besides some precise issues [like contractual or (more restrictively) non-contractual obligations ${ }^{36}$ ], a general rule of applying or taking compulsory into account foreign overriding mandatory rules still does not exist. Actually, Article 19 of the Swiss Code on Private International Law remains an exception.

(c) Another model could be Article $31 \S 2$ of the Portuguese Act (of 1985) on cultural objects, whereby, subject to reciprocity, contracts concluded in Portugal and regarding a cultural object imported in this country in violation of the law of its State of origin, are null and void.

(d) Another very interesting proposal aims at replacing the traditional conflictof-laws rule of the lex rei sitae regarding cultural objects by a new one, designating as applicable either the law of the State were the object has been stolen (the lex furti $)^{37}$ or the law of the State of origin ${ }^{38}$.

(e) Last but not least, international Conventions, like the Unidroit Convention (1995), constitute reliable weapons against theft and illegal export of cultural objects, provided that a great number of import States ratify these Conventions or adhere to them.

34 Bleckmann, 1974: 112-132.

35 It is quite doubtful whether foreign States will recognize this exclusive competence of Greek courts.

36 Rome I Regulation (art. 9), and Rome II Regulation (art. 16) respectively.

37 Autocephalous Greek-Orthodox Church of Cyprus v Goldberg, U.S. District Court for the Southern District of Indiana, 3. 8. 1989, 717 F. Supp. 1374; U.S. Court of Appeals for the Seventh circuit, 4.10.1990, 917 F. 2d 278, 1990 U.S. App. Decision (in the case of Panaghia Kanakaria's mosaics)]

38 Despite the difficulties of designating that State; it seems that Art. 12 of the Council Directive 93/7/EEC, repeated in Directive 2014/60/EU (a technically bad and confusing provision), might be considered as a formula of the lex originis. 
Though the UNESCO Convention (1970) is a public international law Convention establishing important principles and providing for obligations of States, but not offering to States or individuals remedies against thieves or persons involved in illicit acts, the Unidroit Convention fills in the gaps in the field of private law ${ }^{39}$. Beside the fact that it serves as a source of inspiration for national Courts ${ }^{40}$, regional or international instruments (Directive 2014/60/EU, recital no. 16), and Codes of Ethics ${ }^{41}$, the Unidroit Convention rectifies (without retroactivity) both bad solutions referred supra in Winkworth and Ortiz cases.

(i) Regarding stolen items or cultural objects unlawfully excavated which are considered stolen (according to Article $3 \S 2)^{42}$, the Convention is clear: "The possessor of a cultural object which has been stolen shall return it" (Article $3 \S$ 1). Bona fides of the possessor is irrelevant regarding the ownership of the object and its restitution. The concept of a stolen good in the sense of the Convention is broad enough to include not only all kinds of appropriation of an item belonging to another person but also "all the felonious takings"43, if I may use the terms of the American Courts in the cases Turley and Schultz. In order to avoid any difficulty of the requesting State regarding the proof of its ownership over the illegally excavated cultural object, one could recommend the States to adopt a rule establishing the State ownership over all cultural objects coming from excavations, as it is the case, e.g., in Egypt, Greece, Iran, Italy ${ }^{44}$.

39 Although the Unidroit Convention has not been ratified yet by some great States involved in the illegal traffic of cultural objects (France, Germany, the Netherlands, Russia, Switzerland, the United Kingdom, the United States), it nevertheless constitutes in the field of private law "le seul effort international et universel sérieux" against the illegal traffic of these objects: Lalive d'Epinay, 1996: 49; cf. Droz, 1997: 279-280.

40 Government of the Islamic Republic of Iran v The Barakat Galleries Limited [2007] EWCA Civ. 1374, as well as L. v Chambre d'accusation du canton de Genève, BGE 123 II 134, although the mention Unidroit Convention was not adopted by the interested States (the United Kingdom in the first case, and France and Switzerland in the second one).

41 See, for example, the ICOM Code of Ethics for Museums, Ch. 7, available at https://icom. museum/wp-content/uploads/2018/07/ICOM-code-En-web.pdf; International Code of Ethics for Dealers in Cultural Property (UNESCO 1999), available at https://unesdoc.unesco.org/ ark:/48223/pf0000121320.

42 The assimilation of the illegally excavated to the stolen cultural objects, and consequently the obligation to restitute them unconditionally, constitutes the most effective weapon against the greatest danger threatening national cultural heritage, i.e. the illegal excavation. Such an excavation destroys all scientific information concerning the items. "Archaeological resources from past epochs can never be renewed"; Nafziger, Paterson, Renteln, 2010: 252-256.

43 Gerstenblith, 2009: 30. For a more analytical account, see Vrellis, 2015: 574-575.

44 Vrellis, 2015: 576-577; Sheng, 2009: 10. 
(ii) Regarding illegal export, the protection afforded by the Convention is (unfortunately) minor, but it may prevent solutions like that in Ortiz case. Article $5 \S 1$ and $\S 3$ states that "A Contracting State may request the Court or other competent authority of another Contracting State to order the return of a cultural object illegally exported from the territory of the requesting State"; and that "the Court or other competent authority of the State addressed shall order the return of an illegally exported cultural object if [the protection here is submitted to conditions] the requesting State establishes that the removal of the object from its territory significantly impairs one or more of the following interests: (a) the physical preservation of the object or of its context; (b) the integrity of a complex object; (c) the preservation of information of, for example, a scientific or historical character; (d) the traditional or ritual use of the object by a tribal or indigenous community, or establishes that the object is of significant cultural importance for the requesting State ${ }^{\prime \prime 4}$.

Two other important points in the Unidroit Convention must be highlighted:

(a) Regarding some categories of stolen cultural objects, those forming an integral part of an identified monument (like the sculptures and reliefs of the Parthenon), or an archaeological site, or those belonging to a public collection, ${ }^{46}$ the Convention provides that a claim for their restitution "shall not be subject to time limitations other than a period of three years from the time when the claimant knew the location of the cultural object and the identity of its possessor", even though the possessor had acted bona fide (Article $3 \S 4$ ). Thus, it establishes the principle of imprescriptibility, accompanied (unfortunately) by the possibility of a State to "declare that [such] a claim is subject to a time limitation of 75 years or such longer period as is provided in its law" (Article 3 $\S 5$ ). (b) In case of restitution of a stolen good or an illegal export, the bona fide possessor shall be entitled, at the time of its return, to payment by the requesting State of fair and reasonable compensation (Articles 4 and 6). As a principle, this is a bad solution since there is no bona fide acquisition in cultural objects' illicit traffic. Pretending to be a bona fide possessor is a lie, a fiction, a creature of a romantic imagination. Nothing more! Anyway, so it was agreed in the Unidroit Convention ${ }^{47}$. Nevertheless, what is interesting regarding this point is that in determining whether the possessor of an illegally exported cultural good is bona fide, "regard shall be had to the circumstances of the acquisition, including the absence of an export certificate required under the law of the requesting State"

45 The EU Directive 2014/60/EU establishes a system of administrative cooperation between Central Authorities of Member States, using the Internal Market Information System (IMI).

46 Regarding the meaning of 'public collection' in the framework of the Convention see art. $3 \S 7$; cf. the definition for the purposes of Directive 2014/60/EU in its art. 2 no. (8).

47 Cf. an analogous system in Directive 2014/60/EU. 
of origin (Article $6 \S 2$ ). I would be happier if the Convention had been more courageous at this point and if it had considered the absence of the certificate as a presumption of the mala fides of the possessor. But anyway, in the adopted rule one may discover a first step towards using the most effective weapon in the fight against the illicit traffic of cultural object, i.e. the certificate of origin. The absence of such a certificate must always lead to the nullity of any transfer of the object and the reason to refuse any compensation to the possessor. Let us hope that it will be so in the future.

\section{Conclusion}

Despite the progress realized during the last decades regarding the protection of the cultural heritage, there is still a lot to do in order to arrive in a satisfactory regime $^{48}$. The attention of those who will deal with this issue in the future must be in particular focused on: (a) the possible assimilation of the status of the illegally exported cultural objects to that of stolen objects, in order to increase the protection, combined with an effort to limit to some extent the categories of cultural objects deserving higher protection; (b) to endow with more efficiency the certificates of origin; (c) to rectify or (even better) to abolish the regime of the so called bona fide purchase of cultural objects; and (d) to fight for unconditional return of stolen or illegally exported cultural objects to the State of their origin, without pretexts of any kind.

\section{References}

Asam, H. (2004). Rechtsfragen des illegalen Handels mit Kulturgütern - Ein Überblick, in Festschrift für Erik Jayme, vol. 2. München: Sellier. European Law Publishers. 1651-1668

Bleckmann, A. (1974). Sittenwidrigkeit wegen Verstosses gegen den ordre public international - Anmerkung zum Urteil des BGH vom 22. Juni 1972, ZaöRV 34. $112-132$

Clerici, R. (1989). La protection des biens culturels vis-à-vis des règles italiennes de conflit, Riv. dir. intern. priv. proc. 25 (4). 799-808

Domínguez-Matés, R. (2008). The international prtotection of cultural heritage during non-traditional armed conflicts, including acts of terrorism", in Nafziger, J.A.R., Scovazzi, T. (eds.), Le patrimoine culturel de l'humanité. Leiden/Boston: Martinus Nijhoff Publishers. 851-882

48 See also Asam, 2004: 1668. 
Dromgoole, S. (ed.), (2006). The protection of the Underwater Cultural Heritage - National perspectives in light of the UNESCO Convention 2001 (2nd ed., Leiden: Martinus Nijhoff)

Droz, G. (1997). La Convention d'Unidroit sur le retour international des biens culturels volés ou illicitement exportés (Rome, 24 juin 1995), Revue Critique d.i.p. 86 (2). 239-281

Elia, R. (1995). Greece v Ward: The return of Mycenaean Artifacts, JCP 4 (1). 119-128

Gerstenblith, P. (2009). Schultz and Barakat: Universal Recognition of National Ownership of Antiquities, Art Antiquity and Law 14 (1). 21-48

Kamga, M. (2008). La Convention pour la protection des biens culturels en cas de conflit armé de 1954 et ses deux Protocoles de 1954 et de 1999, in Nafziger, J.A.R., Scovazzi, T. (eds.), Le patrimoine culturel de l'humanité . Leiden/Boston: Martinus Nijhoff Publishers. 817-849

Katsonopoulou, D., Soter, St. (2005). Discoveries at ancient Helike (Jan. 2005) Retrieved 20 February 2019 from http://www.helike.org/paper.shtml

Lalive d'Epinay, P. (1996). Une avancée du droit international: la Convention de Rome d'Unidroit sur les biens culturels volés ou illicitement exportés, $R D U 1$ (1). (1996) 40-58

Loulanski, T (2006). Revising the concept for cultural heritage: The argument for a functional approach, IJCP 13. 207-233

Merryman, J.H. (1985). Thinking about the Elgin Marbles, Michigan L. Rev. 83. 1881-1923

Nafziger, J.A.R., Paterson, R.K., Renteln, A.D. (2010). Cultural Law - International, Comparative, and Indigenous, Cambridge University Press

Proposal for a Regulation of the European Parliament and of the Council on the import of cultural goods, Retrieved 20 February 2019 from http://www.europarl.europa.eu/RegData/commissions/imco/inag/2019/01-16/CJ33_AG(2019)632807_ EN.pdf

Sheng, G. (2009). Recovering illegally removed cultural property and improving cultural property protection: A Chinese perspective, Art, Antiquity and Law 14 (1). 1-19

Siehr, K. (1998). The protection of Cultural Property: the 1995 Unidroit Convention and the EEC Instruments of 1992/93 compared, ULR 3 (2-3) (in memory of M. Evans). 671-683 
Siehr, K. (1993). International art trade and the law, RCADI vol. 243. 9-292

Trevisanut, S. (2008). Le régime des épaves des navires d'Etat dans la Convention UNESCO sur la protection du patrimoine culturel subaquatique, in Nafziger, J.A.R., Scovazzi, T. (eds.), Le patrimoine culturel de l'humanité. Leiden/Boston: Martinus Nijhoff Publishers. 643-686

Vrellis, Sp. (2015). Les biens archéologiques et la Convention d'Unidroit (1995) sur les biens culturels volés ou illicitement exportés, ULR 20. 568-582

Vrellis, Sp. (2014). Règles de déontologie en matière de biens culturels", in Essays in Honour of Laura Picchio Forlati. Torino: G. Giappichelli Editore. 477-486

Vrellis, Sp. (2006). The new Act no 3028/2002 on the Protection of the Antiquities and the Cultural Heritage in general, in Festschrift für Apostolos Georgiades zum 70. Geburtstag. München, Athen, Bern: C.H. Beck, Ant.N. Sakkoulas, Stämpfli. 425-463

Vrellis, Sp. (2005). La protection du patrimoine culturel subaquatique: Regards sur la Convention de l'UNESCO de 2001, in Pacis Artes - Obra Homenaje al Professor J. D. Gonzáles Campos vol. I. Madrid: UAM, Eurolex editorial. 823-840

Vrellis, Sp. (2004). La notion de l'héritage culturel dans la nouvelle loi grecque sur la protection des antiquités, in Festschrift für Erik Jayme, vol. 2. München: Sellier. European Law Publishers. 1779-1788

Vrellis, Sp. (2003). La Convention d'Unidroit sur les biens culturels volés ou illicitement exportés: un acquis culturel, in La protection internationale des biens culturels -Regard dans l'avenir (Actes de Colloque, Athènes 23.11.2001). Athènes, Komotini: éd. Ant. N. Sakkoulas. 17-46

Vrellis, Sp. (1996). Le statut des biens culturels en droit international privé in Académie Internationale de Droit Comparé -XIV Congrès international du droit comparé, Athènes 1994-Rapports généraux Athens/The Hague: Ant.N. Sakkoulas Publishers, Kluver Law International. 221-249

Williams, S. (1997). Patrimoine sous-marin: La course aux trésors, Sources UNESCO no 87 (février 1997), p.7-8 [Electronic version], Retrieved 20 Feb. 2016 from https://unesdoc.unesco.org/ark:/48223/pf0000105111_fre

Zhao, Y-j (2008). The relationships among the three multilateral regimes concerning the Underwater Cultural Heritage, Nafziger, J.A.R., Scovazzi, T. (eds.), Le patrimoine culturel de l'humanité. Leiden/Boston: Martinus Nijhoff Publishers. 601-641 


\title{
Dr Spyridon Vrellis,
}

Проф. емеритус, Правни факултет, Универзитет у Атини, Грчка

Проф. др. х.Ц. ЕЛТЕ Будимпешта

\section{ПИТАЊА ЗАШТИТЕ КУЛТУРНОГ НАСЛЕЪА}

\begin{abstract}
Резиме
Циљ овог рада је прикаже настојања и предузете активности међународних организација и националних законодавстава, а нарочито грчког законодавства, у погледу заштите културног наслеђа одређене државе, које се такође одређује као културна баштина или културно добро. Од самог почетка, током и након стварања модерне државе, Грчка је веома посвећена заштити културних добара, нарочито у оквиру међународне заштите ових права, јер се често суочава са крађом и пљачком предмета своје културне баштине. Како би се повес́ала заштита отуђених културних добара, Грчка игра активну улогу на међународној сцени кроз борбу за реституцију украдених или незаконито извезених културних добара и њихов повраћај у земље поријекла.

Упркос напретку који је током последњих дещенија остварен у погледу заштите културне баштине, још увек има доста спорних питања која се морају разрешити како би се постигао задовољавајус́и режим заштите културних добара. Они који ће се убудус́е бавити овом материјом треба да посвете нарочиту пажњ следећим питањима: (1) омогућити изједначавање статуса незаконито извезених културних добара са статусом украдених добара, како би се повес́ао степен њихове заштите, у комбинацији са настојањем да се у одређеној мери ограниче категорије културних објеката који заслужују већи степен заштите; (2) осигурати ефикасније дејство сертификата о пореклу; (3) поправити или (још боље) укинути режим тзв. бона фиде куповине културних добара; и (4) наставити борбу за реституцију украдених или незаконито извезених културних добара и њихов безусловни повраћај у државу поријекла, без икаквих изговора и уступака.
\end{abstract}

Кључне речи: Заштита културног наслеђа, културна баштина, културно добро, реституција. 